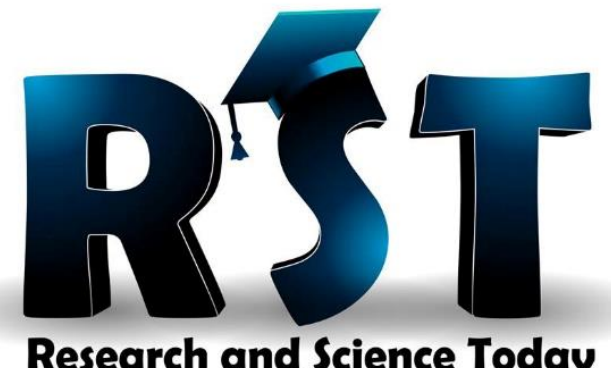

\title{
DOI: 10.38173/RST.2020.S1.8:67-74
}

Title:

IMMUNOGLOBULINS: FUNCTIONS, BIOSYNTHESIS AND

BIOLOGICAL PROPERTIES

\begin{tabular}{c}
\hline \\
Daniela BADEA \\
Authors: \\
Amelia GENUNCHE-DUMITRESCU \\
Mihail BADEA \\
Cristian MARINAȘ \\
Tiberiu ȚENEA COJAN
\end{tabular}

Section: Medical Sciences

Issue: $\quad$ Supplement $1 / 2020$

Received: 15 March 2020

Accepted: 13 April 2020
Revised: -

Available Online: 2 June 2020

Paper available online HERE 


\title{
IMMUNOGLOBULINS: FUNCTIONS, BIOSYNTHESIS AND BIOLOGICAL PROPERTIES
}

\author{
Daniela BADEA ${ }^{1}$ \\ Amelia GENUNCHE-DUMITRESCU ${ }^{2}$ \\ Mihail BADEA ${ }^{3}$ \\ Cristian MARINAȘ ${ }^{4}$ \\ Tiberiu T,ENEA COJAN ${ }^{5}$
}

\begin{abstract}
:
IMMUNOGLOBULINS SYNTHESIS IS THE DEFINING PROPERTY OF B LYMPHOCYTES AND PLASMA CELLS. RESTING B LYMPHOCYTES SYNTHESIS ONLY SMALL AMOUNTS OF IMMUNOGLOBULINS THAT INSERTED INTO THE CELL MEMBRANE. PLASMA CELLS ARE SPECIALIZED TO PRODUCE AND SECRETE LARGE AMOUNTS OF IMMUNOGLOBULINS. ANTIBODY MOLECULES HAVE TWO MAJOR FUNCTIONS:

ANTIGEN BINDING IS A FUNDAMENTAL FUNCTION WICH DEPENDS ON THE VARIABLE REGIONS LOCATED ON THE Fab REGION OF THE MOLECULE AND FC REGION INTERESTED IN PLACENTAL TRANSFER, COMPLEMENT FIXATION AND BINDING TO FC RECEPTORS. BIOLOGICAL PROCESSES (OPSONIZATION, MAST CELL DEGRANULATION, etc.) ARE POSSIBLE DUE TO THE PRESENCE OF RECEPTORS FOR FC PORTION FOR VARIOUS TYPES ON GI ON CELLS THAT PARTICIPATE IN IMUNITY
\end{abstract}

KEY WORDS: IMMUNOGLOBULINS, COMPLEMENT, Fc RECEPTORS.

\section{INTRODUCTION}

Synthesis of immunoglobulins represents the defining function of the B lymphoid line, the plasma cells, the final cellular elements of the series, being able to synthesize antibodies in moderate amounts. Heavy and light chains are synthesized on different

\footnotetext{
${ }^{1}$ Clinical Hospital of Emergency Craiova, Department of Physiology, University of Medicine and Pharmacy Craiova, Romania

${ }^{2}$ Clinical Hospital of Emergency Craiova, $1^{\text {st }}$ Medical Clinic, University of Medicine and Pharmacy Craiova, Romania

${ }^{3}$ Clinical of Hematology, Filantropia Hospital of Craiova

${ }^{4}$ Clinical Hospital of Emergency Craiova, Department of Anatomy, University of Medicine and Pharmacy Craiova, Romania

${ }^{5}$ CFR Hospital, Surgery Department, University of Medicine and Pharmacy Craiova, Romania
} 


\section{RSI}

polyribosomes, but the normal plasma cell produces balanced amounts of $\mathrm{H}$ (heavy) and $\mathrm{L}$ (light) chains, so are formed only complete immunoglobulin molecules ${ }^{6}$.

Antibodies are antigens specific proteins produced by plasma cells; belong to immunoglobulin (Ig) family; located in blood and extravascular tissues, secretions and excretions; bind pathogenic microorganism and their toxins in extracellular compartiments.

Structure configuration of antibody: chains: light $(\mathrm{L})$, heavy $(\mathrm{H})$; domains: variable (V) - single $\mathrm{V}$ domain in $\mathrm{H}$ and $\mathrm{L}$ chains; constant (C) - single $\mathrm{C}$ domain in $\mathrm{L}$ chains; three to four $(\mathrm{C})$ domains in $\mathrm{H}$ chains.

\section{MAIN TEXT}

\section{Classes (isotypes) of immunoglobulines}

Classes based on constant region of heavy chains: immunoglobulin A (alpha heavy chains); Immunoglobulin D (delta heavy chains); immunoglobulin E (epsilon heavy chains); immunoglobulin G (gamma heavy chains); immunoglobulin M (Mu heavy chains).

Differentation on heavy chains:

- length of $\mathrm{C}$ region

- location of disulphide bonds, hinge region, distribution of carbohydrate

Classes have different effector function

Structure, some properties and functions of Ig classes (table no. 1)

\begin{tabular}{|c|c|c|c|c|c|}
\hline & $\mathrm{IgG}$ & $\operatorname{IgM}$ & $\operatorname{Ig} \mathrm{A}$ & $\operatorname{IgD}$ & $\operatorname{IgE}$ \\
\hline Structure & Monomer & Pentamer & Dimer & Monomer & Monomer \\
\hline $\begin{array}{l}\text { Percentaje } \\
\text { serum } \\
\text { antibodies }\end{array}$ & $80 \%$ & $5-10 \%$ & $10-15 \%$ & $0.2 \%$ & $0.002 \%$ \\
\hline Location & $\begin{array}{l}\text { Blood, lymph, } \\
\text { intestine }\end{array}$ & $\begin{array}{l}\text { Blood, lymph, B } \\
\text { cell surface } \\
\text { (monomer) }\end{array}$ & $\begin{array}{l}\text { Secretions } \\
\text { (tears, saliva, } \\
\text { intestine, } \\
\text { milk), blood } \\
\text { and lymph }\end{array}$ & $\begin{array}{l}\text { B-cell surface, } \\
\text { blood and lymph }\end{array}$ & $\begin{array}{l}\text { Bound to mast } \\
\text { cells and } \\
\text { basophils } \\
\text { throughout } \\
\text { body. Blood }\end{array}$ \\
\hline Half-life & 23 days & 5 days & 6 days & 3 days & 2 days \\
\hline $\begin{array}{l}\text { Complement } \\
\text { fixation }\end{array}$ & Yes & Yes & No & No & No \\
\hline $\begin{array}{l}\text { Placental } \\
\text { transfer }\end{array}$ & $\begin{array}{l}\text { Yes (the only } \\
\text { Ig) }\end{array}$ & No & No & No & No \\
\hline $\begin{array}{l}\text { Know } \\
\text { functions }\end{array}$ & $\begin{array}{l}\text { Enhances } \\
\text { phagocytosis, } \\
\text { neutralizes } \\
\text { toxins and } \\
\text { virises, protects } \\
\text { fetus and } \\
\text { newborn }\end{array}$ & $\begin{array}{l}\text { First antibodies } \\
\text { produced during } \\
\text { an infection. } \\
\text { Effective against } \\
\text { microbes and } \\
\text { agglutinanting } \\
\text { antigens }\end{array}$ & $\begin{array}{l}\text { Localized } \\
\text { protection of } \\
\text { mucosal } \\
\text { surface. } \\
\text { Provides } \\
\text { immunity to } \\
\text { infant } \\
\text { digestive tract }\end{array}$ & $\begin{array}{l}\text { On B cell } \\
\text { surface, initiate } \\
\text { immune } \\
\text { response, } \\
\text { discriminate } \\
\text { between naïve } \\
\operatorname{IgD}(+) \text {, memory } \\
(\operatorname{Ig} \text { neg) and } \\
\text { plasma cells (Ig } \\
\text { neg) }\end{array}$ & $\begin{array}{l}\text { Allergic } \\
\text { reactions. } \\
\text { Possibly lysis } \\
\text { of worms }\end{array}$ \\
\hline
\end{tabular}

\section{FUNCTIONS OF Ig CLASSES}

Immunoglobulin $\mathrm{M}(\operatorname{IgM})$ is the first Ig to be made by the fetus and the first Ig to be made by a virgin B cells when it is stimulated by antigen and the most efficient Ig at complement fixation. It is produced early in immune responses. Serum immunoglobulin

\footnotetext{
${ }^{6}$ Kleine TO. Structure and biosynthesis of antibodies. Z Kein Chem Klin Biochem, 1969, Jul 7(4):313-24
} 
(Ig)M provides the initial response to foreign antigen and plays a regulatory role in subsequent immune response development, accelerating the production of high-affinity $\operatorname{IgG}^{7}$.

Immunoglobulin A (IgA) is the major class of $\mathrm{Ig}$ in secretions - tears, saliva, colostrum, mucus. It is a major immunoglobulin isotype in the gut and plays a role in maintenance of gut homeostasis. IgA. has multiple functions in the gut, such as to regulate microbiota composition, to protect intestinal epithelium from pathogenic microorganisms, also to help for immune-system development. The liver is the front-line organ that receives gut-derived products through the portal vein, implying that the liver could be severely affected by a disrupted intestinal homeostasis. Some liver diseases, like alcoholic liver disease are associated with an altered composition of gut microbiota and increased blood endotoxin levels. Deficiency of SIgA function appears as a significant factor for the pathogenesis of liver diseases associated with altered gut microbiome ${ }^{8}$. The secretory $\operatorname{IgA}$ molecule is assembled in several stages; the plasma cell synthesizes dimeric IgA molecule (including peptide $\mathrm{J}$ ), and epithelial cell attaches to the secretory component and releases the Ig molecule into the digestive lumen'.

IgG is a major serum glycoprotein that exerts the role of antibody in the immune system. It has the highest concentration in human serum, the ability to activate complement, both classically and alternately way and binding to cells: monocytes, macrophages, PMNs some lymphocytes have Fc receptors for the Fc region of IgG. Also, IgG is a good opsonin; binding of $\mathrm{IgG}$ to $\mathrm{Fc}$ receptors on other types of cells results in the activation of phagocytosis. Participates in microbial opsonization and is able to cross the maternal-fetal barrier. This multifunctional glycoprotein couples antigen recognition with a variety of effector functions promoted via interactions with various IgG-binding proteins. Carbohydrate fragments of IgG glycoproteins critically affect their antibody functions, especially the effector functions mediated by the interactions Fc $\gamma$ receptor interactions $(\mathrm{Fc} \gamma \mathrm{Rs})^{10}$.

IgE attaches to mast cells and upon interaction with the specific allergen causes degranulation of these cells, with the release of chemical mediators responsible for the clinical manifestations of type I hypersensitivity (allergic asthma, allergic rhinitis, food allergy, atopic dermatitis, some forms of drug allergy, and insect sting allergy). IgE participates in both the immediate allergic response and the late-phase or chronic inflammatory response in the skin and lungs ${ }^{11}$. IgE also plays a role in parasitic heminth diseases.

IgD exists in serum only as a monomer and it is a receptor on B-cell membranes for antigen. It is found on the B-cell membranes of $15 \%$ of newborns and again on adult peripheral blood lymphocytes in conjunction with IgM.

\section{IMMUNOGLOBULIN BIOSYNTHESIS}

Immunoglobulin synthesis is the defining function of the B lymphoid line, plasma cells being able to synthesize antibodies in significant amounts.

\footnotetext{
${ }^{7}$ Ehrestein MR, Cook HT. Neuberger MS. Deficiency in serum IgM predisposes to development of IgG antibodies. J Exp Med, 2000 apr3; 191(7):1258-9

${ }^{8}$ Inamine T, Schnabl B. Immunoglobulin A and liver diseases. J Gastroenterol, 2018 jun; 53(6):691-700

9 Johansen FE, Braathen R, Brandtzaeg P. Role of J chain in secretory immunoglobulin formation. Scand J Immunol, 2000, sept; 52(3), 240-8

${ }^{10}$ Yagi H, Yanaka S, Kato K. Structure and dynamics of immunoglobulin G glicoproteins. Adv Exp Med Biol, 2018; 1104; 219-235

${ }^{11}$ Platts-Mills TA. The role of immunoglobulin E in allergy and asthma. Am J Respir Crit Med, 2001, oct 15; 164(8) S1-5
} 


\section{RST}

Resting B lymphocytes synthesize only small amounts of immunoglobulins that will be expressed on the cell membrane, becoming antigen receptors.

Plasma cells are B cells in the final stage of maturation, in the G1 phase. Plasma cells have limited mitotic activity, but are specialized to produce and secrete large amounts of immunoglobulins. Abundant cytoplasm, extremely rich in endoplasmic reticulum, is the morphological marker of an important protein synthesis.

Heavy and light chains are synthesized on different polyribosomes. The plasma cell produces balanced amounts of $\mathrm{H}$ (heavy) and L (light) chains, so that only complete immunoglobulin molecules are formed, without surpluses. The plasma cell produces balanced amounts of $\mathrm{H}$ (heavy) and L (light) chains, so that only complete immunoglobulin molecules are formed, without surpluses.

Malignant transformation maintains balanced synthesis of heavy and light chains, in most cases, but some malignant lymphoproliferations may cause the synthesis of excess light chains. With low molecular weight, they are excreted in the urine as Bence-Jones proteinuria. Malignant B proliferations are clonal character, and as a result, synthesized immunoglobulins or light chains are also monoclonal character (they are identical).

Plasma cells can synthesize free light chains, not free heavy chains. Heavy chains are synthesized and transported to the endoplasmic reticulum, where they are glycosylated, and subsequently associated with light chains they form complete immunoglobulin molecules. In the absence of light chains, free heavy chains in the cytoplasm associate through the $\mathrm{CH} 1$ domain with a protein that retains them intracytoplasmic ${ }^{12}$.

\section{Synthesis of polymeric immunoglobulins}

Polymer immunoglobulins (IgM, IgA) have an additional polypeptide chain, the $\mathbf{J}$ chain, which can be synthesized by all plasma cells, including those that produce IgG. However, the $\mathrm{J}$ chain is incorporated only in the polymeric forms of $\operatorname{IgM}$ and $\operatorname{IgA}$. IgM are assembled in two steps: in a first step the monomeric units are synthesized, then five IgM monomers join with a $\mathbf{J}$ chain through covalent bonds, forming the pentamer molecule. The assembly coincides with secretion in some cells, while in others there are pentameric, intracellular forms.

\section{Synthesis of secretory IgA immunoglobulin}

The secretory IgA molecule is also assembled in several phases, each unfolding in a different cell type.

Dimeric IgA contains two monomeric subunits of $\operatorname{IgA}$ and a $\mathrm{J}$ chain associated by disulfide bridges. Most dimeric IgA molecules are synthesized by the submucosal plasma cells (digestive tract, respiratory tract, etc.), a minor fraction (approximately 10\%) being synthesized in the hematogenous marrow ${ }^{13}$.

Secretory component $(\boldsymbol{C S})$ is synthesized in epithelial cells, where are the final assembly of secretory IgA.

CS is responsible for secretion of IgA in the mucous membranes. This process involves uptake of dimeric IgA, assembly of the IgA-CS complex and secretion by the mucosal cells.

\footnotetext{
12 Donald M. Weir, John Stewart. Biosynthesis and metabolism of immunoglobulin. In Immunology 8th ed; Churchill Livingstone, 1997

${ }^{13}$ Schrolder HW Jr, Cavacini L. Structure of immunoglobulins. J Allergy Clin Immunol, 2010, feb 125 (2 suppl)
} 
The mechanism of synthesis and excretion of secretory IgA molecules. The dimeric $\operatorname{IgA}$ molecule is synthesized by plasma cells found in the submucosa and excreted in the interstitium. The intestinal epithelial cell takes up the dimeric $\operatorname{IgA}$ molecule via the polyimmunoglobulin receptor. The dimeric IgA complex - polyimmunoglobulin receptor is internalized in the cytoplasm, where important portions of the receptor molecule are excised, thus structuring the secretory component that attaches to $\operatorname{IgA} \operatorname{IgA}$ is secreted into the lumen, where it provides anti-infective protection to the mucosa ${ }^{14}$. Secretory $\operatorname{IgA}$ can modulate microbial communities and pathogenic microbes via several mechanisms: agglutination and exclusion from the epithelial surface, neutralization, or via host immunity and complement activation $^{15}$.

Similar mechanisms of transport also occur in the liver. Hepatocytes produce Poly$\operatorname{IgR}$, bind and internalize dimeric IgA that reaches the liver through the portal circulation and transforms it into secretory $\operatorname{IgA}$ that will be eliminated in the bile.

Minimum amounts of secretory IgA produced in the liver normally pass into the systemic circulation. Elevated blood levels of $\operatorname{IgA}$ secretory are present in some liver diseases. It is considered that dimeric IgA taken from the intestine through the mesenteric lymphatics is released into the systemic circulation, due to hepatocyte suffering that compromises its secretion to the bile duct.

\section{BIOLOGICAL PROPERTIES OF IMMUNOGLOBULINS}

Antibody molecules have two functionally distinct regions; antigen binding is a function fundamentally dependent on the variable regions located in the Fab area of the molecule and the $\mathrm{Fc}$ region that give the immunoglobulin molecule the ability to place placental transfer, complement activation and binding to Fc receptors.

Placental transfer. In humans, IgG is the only major immunoglobulin, transferred from mother to fetus through the placenta.

Placental $\operatorname{IgG}$ transfer is an active process; $\mathrm{IgG}$ concentration in the fetal circulation is often higher than in maternal blood. The normal fetus synthesizes only small amounts of IgM, being dependent on IgG transferred transplacental a few months after birth.

Selectivity of IgG transport was explained by the Brambell receptor theory, that also intervenes in IgG catabolism ${ }^{16}$. Trophoblast cells on the maternal side of the placenta will endocyte plasma containing all types of proteins, but possess only RFc $\gamma$-type receptors, not other immunoglobulins. IgG bound to Fc $\gamma$ receptors in the vesicles will be protected, and by reverse active pinocytosis, will be released into the fetal circulation ${ }^{17}$.

Complement activation. All immunoglobulins are able to fix complement, either classically or alternately way:

1. Activating the classic path. IgG1, IgG3 and IgM molecules are most efficiente in fixing and activating complement in the classical way.

\footnotetext{
${ }^{14}$ Asano M, Komiyana K. Polymeric immunoglobulin receptor. J Oral Sci, 2011, jun, 53(2), 146-56

15 Turula H, Wobus CE. The role of the polymeric immunoglobulin receptor and secretory immunoglobulins during infection and immunity. Viruses, 2018, may 3;10(5); 237

16 Telleman P, Junghans RP. The role of the Brambell receptor (FcRB) in liver: protection and endocytosed immunoglobulin $\mathrm{G}(\mathrm{IgG})$ from catabolism in hepatocytes rather than transport of IgG to bole. Immunology, 2000 Jun;100(2):245-51

17 van Sorge NM, van der Pol, van de Winkel. Fc $\gamma$ R polimorphismas: Implications for function, disease, susceptibility and immunotherapy. Tissue Antigens, 2003 Mar, 61(3), 189-202
} 


\section{RST}

2. Consequences of complement activation. Complement is an extremely important amplifying mechanism that ensures the neutralization of antibody-mediated microbial toxins and the elimination of infectious agents. These effects depend on:

a. Generation and deposition of $C 3 b$ on the membrane of a microorganism, a mechanism that amplifies phagocytosis through cellular receptors for this molecule; $\mathrm{C} 3 \mathrm{~b}$ acts as an opsonin.

b. Perforation of the microbial membrane is dependent by the activation of the late components of the complement (final or C6-C9 attack pathway), which causes the formation of transmembrane channels. Disruption of internal cellular or microbial environment causes membrane/cell lysis ${ }^{18}$.

Binding to Fc receptors. The cell types involved in the immune response bind one or more immunoglobulin isotypes via surface Fc receptors. These receptors are: Fc $\gamma \mathrm{R}$ (IgG receptors), Fc $\alpha \mathrm{R}$ (IgA receptors), FceR (IgE receptors) and Fc $\mu \mathrm{R}$ (IgM receptors).

Fc receptors mediate antibody dependent inflammatory response and cytotoxicity as well as certain autoimmune dysfunctions. Fcgamma receptors interact with IgG antibodies by binding the Fc portion of the antibody in asymmetric fashion creating a 1:1 receptor-ligand stoichiometry ${ }^{19}$.

- FcyRI - high affinity receptor, capable of binding monomeric IgG, expressed exclusively by monocytes and macrophages. lymphocytes.

- Fc $\gamma$ RII - low affinity receptor for IgG, expressed by phagocytic cells, platelets and B NK cells ${ }^{20}$.

- Fc $\gamma$ RIII - the second receptor with low affinity for IgG, expressed by phagocytic and

\section{Significance of Fc $\gamma \mathrm{R}$ binding}

a. The catabolic rate of $\mathrm{IgG}$ and the selective placental transfer of $\operatorname{IgG}$ depend on their interaction with $\mathrm{Fc} \gamma \mathrm{R}$ in the pinocytosis vesicles.

b. IgG mediates phagocytosis for all cells that express $\mathrm{Fc} \gamma \mathrm{R}$ on the membrane (granulocytes, macrophages, etc.), thus, IgG becoming an opsonin. IgG and $\mathrm{C} 3 \mathrm{~b}$ have synergistic opsonin effects and binding/deposition together on the membrane of an infectious agent is one of the most effective ways to remove it.

c. Granulocytes, monocytes/macrophages, NK cells can destroy target cells coated with IgG antibodies (CCDA antibody-dependent cellular cytotoxicity). The killing of target cells does not depend on opsonization, but on the close contact of the NK-target cell lymphocyte and the signals received by it.

Phagocytic cells also express $F c \alpha R$, which under experimental conditions, have the ability to mediate the attachment and phagocytosis of IgA-coated particles. However, the physiological role of this receptor is not completely defined.

For IgE, two specific types of FceR have been defined ${ }^{21}$ :

\footnotetext{
${ }^{18}$ Schmidt BZ, Colten HR. Complement: a critical test of its biological importance. Immunological reviews 178, $2000,166-76$

${ }^{19}$ Radaev S, Sun P. Recognition of immunoglobulins by Fcgamma receptors. Mol Immunol, 2002 may, 38(14), 1073-83

${ }^{20}$ Vidarsson G, Dekkers G, Rispens T. IgG subclasse and allotypes: from structure to effector functions. Front Immunol, 2014, oct 20;5;520

${ }^{21}$ Sutton BJ, Davies AM. Structure and dynamics of IgE-receptor interactions: FceRI and CD23/ FceRII. Immunolog Rev, 2015 nov; 268(1): 222-35
} 
- a low affinity receptor (FceRII), present on most types of granulocytes, which mediates CCDA reactions against nematodes. Infestation with these parasites results in increased IgE synthesis;

- a high affinity receptor (FceRI) expressed on the surface of basophils and mast cells. IgE bound to basophils/mast cells functions as a true cellular receptor. When an IgE molecule bound to FceRI high affinity membrane receptors interacts with the specific antigen, the cell is activated, an event translated by histamine discharges and other mediators in the process of mast cell degranulation. The release of histamine and other biologically active molecules is the basis of the immediate IgE-mediated hypersensitivity reaction ${ }^{22}$.

\section{CONCLUSION}

Immunoglobulins are glycoprotein molecules that are produced by plasma cells (terminally differentiated B cells) in response to an immunogen and which function as antibodies. All antibodies are immunoglobulins and they are found in serum, in body fluids and tissues and bind pathogenic microorganism and their toxins in extracellular compartiments

\section{ACKNOWLEDGEMENTS}

All authors equally contributed in the research and drafting of this paper.

All authors report no pottential conflict of interest.

${ }^{22} \mathrm{Wu}$ LC, Zarrin AA. The production and regulation of IgE by the immune system. Nat Rev Immunol, 2014 Apr ;14(4): 247-59 


\section{RST}

\section{REFERENCES}

1. Abbas AK, Lichtman AH, Pillai S. Cellular and Molecular Immunology, Saunders, imprint of: Elsevier: Inc, eight edition, 2015.

2. Badea M, Badea D, Genunche-Dumitrescu A. Imuno-hematologie clinică. Ed. Sitech, 2013.

3. Catherine Sheehan. Immunoglobulin structure and function, In Clinical Immunology: principles and laboratory diagnosis $2^{\text {nd }}$ ed; Lippincott-Raven, 1997.

4. Chapel H, Haeney M, Misbah $\mathbf{S}$ et al. Essentials of Clinical Immunology, $6^{\text {th }}$ Edition WileyBlackwell, 2014.

5. Delves PJ, Martin SJ, Burton DR et al. Roitt's Essential Immunology. Ed. Wiley, Edition 13, 2017.

6. Gergely J, and Sarmay G. The two binding-site models of human IgG binding Fc $\gamma$ receptor. FASE J, 1998, 4:3275.

7. Hawley L, Ziegler RJ, Clarke BL. Microbiology and Immunology, Lippincot Williams \&Wilkins, sixth ed, 2014.

8. Male D, Brostoff J, Roth DB et al. Immunology, $8^{\text {th }}$ edition, Elsevier. Saunders, 2012.

9. Metzer H. Fc receptors and membrane immunoglobulins, Curr. Opin Immunol, 1999, 3:40.

10. Sompayrac L. How The Immune Sistem Works, Wiley-Blackwell, $5^{\text {th }}$ edition, 2016.

11. Van Oss CJ and van Regenmortel MHV. Immunoglobulin structure and function, Immunochemistry, Marcel Dekker, New York, 1994.

12. Wienands J. The B-cell antigen receptor: formation of signaling complexes and the function of adaptor proteins. Current topics in microbiology and immunology, 2000, 245 (1), p 53-76. 